\title{
Competitiveness and Sustainability of the Hotel Industry: The Case of Hotels in Pampanga
}

\author{
Jean Paolo G. Lacap, RMP, AFBE (Corresponding author) \\ Chair, Management and Entrepreneurship Department, Angeles University Foundation \\ Mac Arthur Highway, 2009, Angeles, Philippines
}

Tel: 63-922-624-0225_E-mail: jeanpao13@yahoo.com

Received: March 18, 2014 Accepted: April 4, 2014 Published: June 5, 2014

doi:10.5296/bms.v5i1.5772ＵRL: http://dx.doi.org/10.5296/bms.v5i1.5772

\begin{abstract}
The study aims to scrutinize the competitiveness and sustainability of the hotel industry in Pampanga, Philippines. Its primary objectives include 1) assessing the competitive intensity and attractiveness of the hotel industry; 2) analyzing the factors affecting the industry; and 3) identifying the issues, concerns, and prospects of the industry, and 4) formulating competitiveness and sustainability frameworks. Through the use of focus-group discussion and in-depth interviewing, the finding revealed that the hotel industry in Pampanga is highly competitive. The results also showed that, despite the bright future of the hotel industry of the province brought about by internal and external factors, still, hotel owners and managers expressed their issues and concerns that can directly and indirectly affect the hotel industry in general. Moreover, to boost the level of competitiveness, the key players which include hotel establishments, the government sector including the provincial tourism office, the regional office of the Department of Tourism (DOT), and the local government units (LGUs) and the academe should help and work hand in hand in promoting and supporting the tourism and hospitality sector of Pampanga. The sustainability framework on one hand includes strategies such as: 1) clear brand image for Pampanga, 2) sustainable/year-round tourist activities, 3) new system of hotel accreditation, 4) law enforcement and security assurance, 5) proper promotion for Pampanga as a tourist destination, 6) improvement of hospitality and tourism infrastructure, and 7) use of technology-enabled hotel reservation system.
\end{abstract}

Keywords: Competitive position, Sustainable niche, Porter's Five Forces Model, SWOT Analysis, Hotel industry, Pampanga, Competitiveness, Business performance, Sustainability 


\section{Introduction}

The massive promotions of the Department of Tourism (DOT) particularly the viral effect of "It's More Fun in the Philippines" campaign led to the increasing number of foreign and local tourists and travellers in the Philippines. The growth of the infrastructure facilities like the sprouting hotels is very much evident around cities and provinces. For instance, in Pampanga, due to the efforts of the different local government units (LGUs) in the province, the arrival of the tourists and travellers also noted as the biggest in region 3. In Central Luzon - 593,945 was recorded as the number of travellers in 2010 while 547,139 in 2009. For the said timeframe, an $8.55 \%$ increase was achieved by the region. Among the 7 provinces - Aurora, Bataan, Bulacan, Nueva Ecija, Pampanga, Tarlac, and Zambales-of the said region, Pampanga had the highest number of travellers in 2009 and 2010 amounting to 146,991 and 123,893 respectively. A growth rate of $18.64 \%$ was recorded for the said region (DOT website, 2012). The development of the Diosdado Macapagal International Airport (DMIA) contributed a lot in inviting both foreign and local tourists and travellers to visit Pampanga since it is near to Metro Manila, the capital of the Philippines. This is one of the reasons why tourism may lead to economic prosperity of one nation. More tourists and travellers mean more employment and investments.

Each hotel client is looking for accommodation facility that can provide service that meets or exceeds his/her expectations. Thus, competitiveness and sustainability of the hotel industry is vital a consideration because the hotel sector is one of the biggest sectors in hospitality and tourism industry. Each hotel, regardless of its classification, may contribute to the overall performance of the local and national hospitality and tourism industry.

In a service sector such as the hospitality and tourism industry, analysis of competitive position and sustainability can be aimed through the application of strategic management tools such as the Porter's Five Forces Model and SWOT analysis. Hospitality industry covers businesses that provide accommodation, food and beverage, or some combination of these activities while travel and tourism encompass a variety of interrelated businesses that provide service to tourists and travellers. In this industry, hotels and restaurants are considered two of the most competitive businesses in the globe. The foodservice industry and the lodging/ accommodation industry are two major players in the hospitality and tourism industry (Enz, 2010).

\subsection{Factors Influencing Competitiveness in the Hospitality Industry}

There are several factors that influence competitiveness in the hospitality industry. The most important factors include interaction abilities, learning organization, human resources, and technology and information technology (Ioncica, Tala, Brindusiu, \& Ioncica, 2008). Interaction abilities are the superior abilities in managing resources shared by several firms (Rodriguez-Diaz \& Espino-Rodriguez, 2006). On the other hand, learning organization refers to the process where a hotel establishment utilizes new global strategy (Bayraktaroglu \& Kutanis, 2003). Furthermore, human resources are the very heart of the industry - people in 
the hospitality industry that create and deliver hospitality products and services. And technology and information technology are the vital strategic variables in achieving competitiveness (Nyheim, McFadden, \& Connolly, 2004). Holjevac (2011) provided a theoretical definition of the relationship among productivity, quality, and competitiveness in Croatian hotel industry. The study revealed that work productivity and competitiveness determine the economic development of a nation and wealth. With this, the study also mentioned that work productivity and competitiveness bring about satisfaction and augments the quality of life of the employees, customers, owners, and the society at large. Tuclea and Padurean (2008) explored the competitiveness of the hospitality industry in Romania. They concluded that there are four factors influencing competitiveness and strategic orientation. These are human resources, innovation, services, and costs. They further averred that there is a general concern towards strategic orientation and increasing competitiveness, and the amount of effort put into these directions is influenced by the form of exploitation and the number of stars (level of comfort).

\subsection{Factors Influencing Sustainability in the Hospitality Industry}

In the study by Nurittamont (2012), organizational commitment, self-efficacy, and business performance of the hotels in Thailand were correlated. The study divulged that organizational commitment and self-efficacy have positively correlation with business performance. From the undertaking, the study attempted to gain understanding on the relationships between organizational commitment, self-efficacy, and business performance through the application of theoretical frameworks to explain the said relationships. It was noted that it is the first known study that directly links organizational commitment to self-efficacy and business performance. Another worked done by Ooncharoen and Ussahawanitchakit (2008) examined the relationships between five dimensions of service culture - high-quality service, communicate openly and honestly, service responsiveness, service failure preventions, and service recovery - that influence organizational excellence and business performance through external environment as moderator of the relationships between organizational excellence and business performance and organizational support, technology orientation, and employee competency as an antecedent of service culture. In totality, the study provided empirical evidence that service culture has a partial significant impact on organizational excellence and performance. It further averred that organizational support, technology orientation, and employee competency have a significant effect with the five dimensions of service culture. On the other hand, $\mathrm{Wu}$ and $\mathrm{Lu}$ (2011) investigated the relationship between customer relationship management (CRM), relationship marketing (RM), and business performance of the hotel industry in Taiwan. The result of the study magnified that CRM has a significant and positive influence of the RM effect, positively affecting business performance. The two authors recommended that, in order to gain higher performance, the different types of hotel establishments should understand their competitive advantage before implementing CRM strategies. Tavitiyaman, Qu, and Zhang (2011) integrated the Porter's five force model and resource-based approach to measure the hotel performance in the United States. The result of the undertaking revealed that the hotels with the advantage of low customer bargaining power 
and low threat of new hotel entrants showed strong human resource and information strategies. Whereas, hotels with the advantage over existing competitors did not show any significant competitiveness of brand image, human resources, and IT strategies. Competitive human resource and IT strategies magnified the rise of hotel performance while competitive brand image strategy has nothing to do with hotel performance.

Navarro and Martinez-Martinez (2007) on one hand analyzed the degree of competitiveness of hotels. They argued that, in order to implement a city marketing program for hotels, municipal managers need to provide support in knowledge creation networks. They also asserted that the size of a hotel is significantly associated with the degree of city promotion initiatives. On one hand, Petre, Stegerean, and Gavrea (2012) studied the comparison of managerial practices on information and communication technology in Cluj and Brasov in Romania. The undertaking demonstrated medium competition level on Romanian tourism market. It also implied that loyalty can be increased given the management of hotels focus on converting the services provided into memorable experience. Moreover, Woo (2007) studied strategy and competitive advantage of Las Vegas hotels focusing on lessons for the Korean hospitality industry. The study reflected the competitive strategies of Las Vegas hotels including strategic cooperation and mergers and acquisitions, development of strategic events, strategic employee management, and constant value creation through competition.

Using the framework of Porter's Five Forces Model, the hotel industry can be clearly scrutinized and later develop strategies that are necessary for the accommodation sector. Using the foundations of industrial organization and economics, the model can measure the degree of competitive and the attractiveness of the market or the industry. The SWOT analysis on one hand can be used to evaluate the internal and external environments affecting the hotel industry. The result of the SWOT analysis is useful in establishing plans in attaining the goals and objectives of the industry. It can also be utilized in the corporate planning for every hotel establishment alongside the analysis of the social, technological, economic, ecological, and political environments of the said industry.

\section{Research Objectives}

The research study had four-fold objectives. First, to assess the intensity of competitiveness and attractiveness of the hotel industry in Pampanga, second is to analyze the macro and micro environments of the hotel industry, third is to identify the issues, concerns, and prospects of the industry, and fourth is to formulate competitiveness and sustainability frameworks to boost the growth of the hotel industry in the said province. These four objectives can be achieved through the use of the Porter's Five Forces Model and SWOT analysis.

\section{Methodology}

The researcher utilized the Porter's Five Forces Model to measure the competitiveness of the hotel industry in Pampanga. Using the five factors - threat of new entrants, threat of substitutes, rivalry among existing firms, bargaining power of buyers, and bargaining power 


\section{Macrothink}

of suppliers - the competitive position of the hotel industry in Pampanga was determined. On one hand, using the environmental analysis tool like SWOT analysis, the internal and external forces affecting the industry was analyzed.

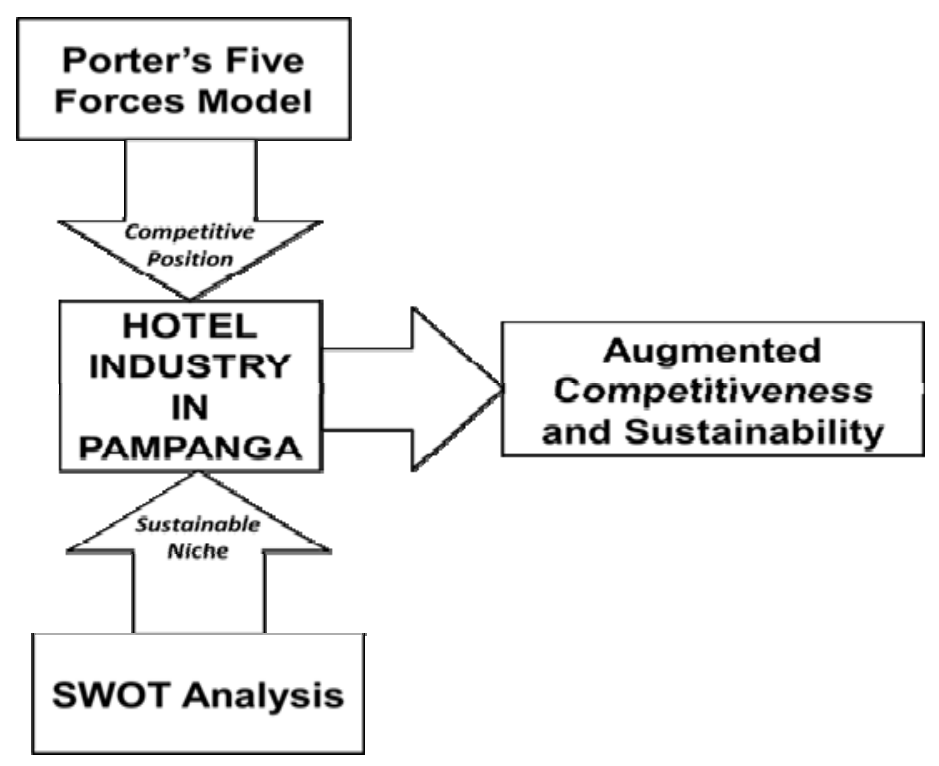

Figure 1. Paradigm of the study

In the research paradigm, the hotel industry in Pampanga was scrutinized through Porter's Five Forces Model to measure the competitive position and SWOT analysis to gauge the sustainable niche. The study also considered the issues, concerns, and prospects in formulating the strategic frameworks in augmenting the level of competitiveness and achieving sustainability in the hotel industry in Pampanga.

Exploratory and descriptive research designs were used to scrutinize the competitiveness and sustainability performance of the hotel industry in Pampanga. Exploratory research is used for a problem that has no clear definition. It aids in determining the right research design, collection of data, and selection of subject. It relies heavily on secondary data. Since there is no thorough research done about the competitiveness and sustainable niche of the hotel industry in Pampanga, an exploratory study is much attuned.

As to study design, the researcher used focus-group discussion and in-depth interviewing. On one hand, a judgmental/purposive sampling technique was utilized in identifying the participants of the study. The respondents comprised 10 hotel managers/owners in Pampanga. Out of the 10 hotels identified, 2 were de luxe hotels, 2 first class, 3 standard hotels, and 3 economy hotels. The DOT Regional director and 3 hospitality and tourism practitioners were also invited to be part of the study. 


\section{Macrothink}

\section{Results and Discussions}

\subsection{Result of the Porter's Five Forces Model Analysis}

In order to measure the competitive position of the hotel industry in Pampanga, the Porter's Five Forces Model was used. The results of the analysis were as follows:

Table 1. Competitive position of the hotel industry in Pampanga

\section{Threats of Substitutes (High)}

- Influx of tourist arrival.

- Existence of hotel alternatives.

- Price and promotion strategies of other lodging / accommodation establishments.

\section{Threats of New Entrants (High)}

- Domination of standard and economy hotels

- Strategic location of the hotel industry

- Angeles City as highly-urbanized area

- Existence of Diosdado Macapagal International Airport (DMIA)

\section{Rivalry Among Existing Hotels (High)}

- High number of Hotels from high-end to low-end

- Low switching cost

- Growth of the hotel industry

- Low degree of product/service differentiation

\section{Bargaining Power of Buyers (High)}

- High number of competitors

- Strategic location of the province

- Elastic demand of hotel clients

- Competitive convergence

- Availability of online sites

\section{Bargaining Power of Suppliers (Low)}

- Availability of hotel manpower

- Existence of 45 colleges \& universities

- Existence of top universities in Central Luzon

\subsection{Result of the SWOT Analysis}

To gauge the sustainable niche of the hotel industry in Pampanga, SWOT analysis was used. The results of this strategic analysis were: 
Table 2. Sustainable niche of the hotel industry in Pampanga

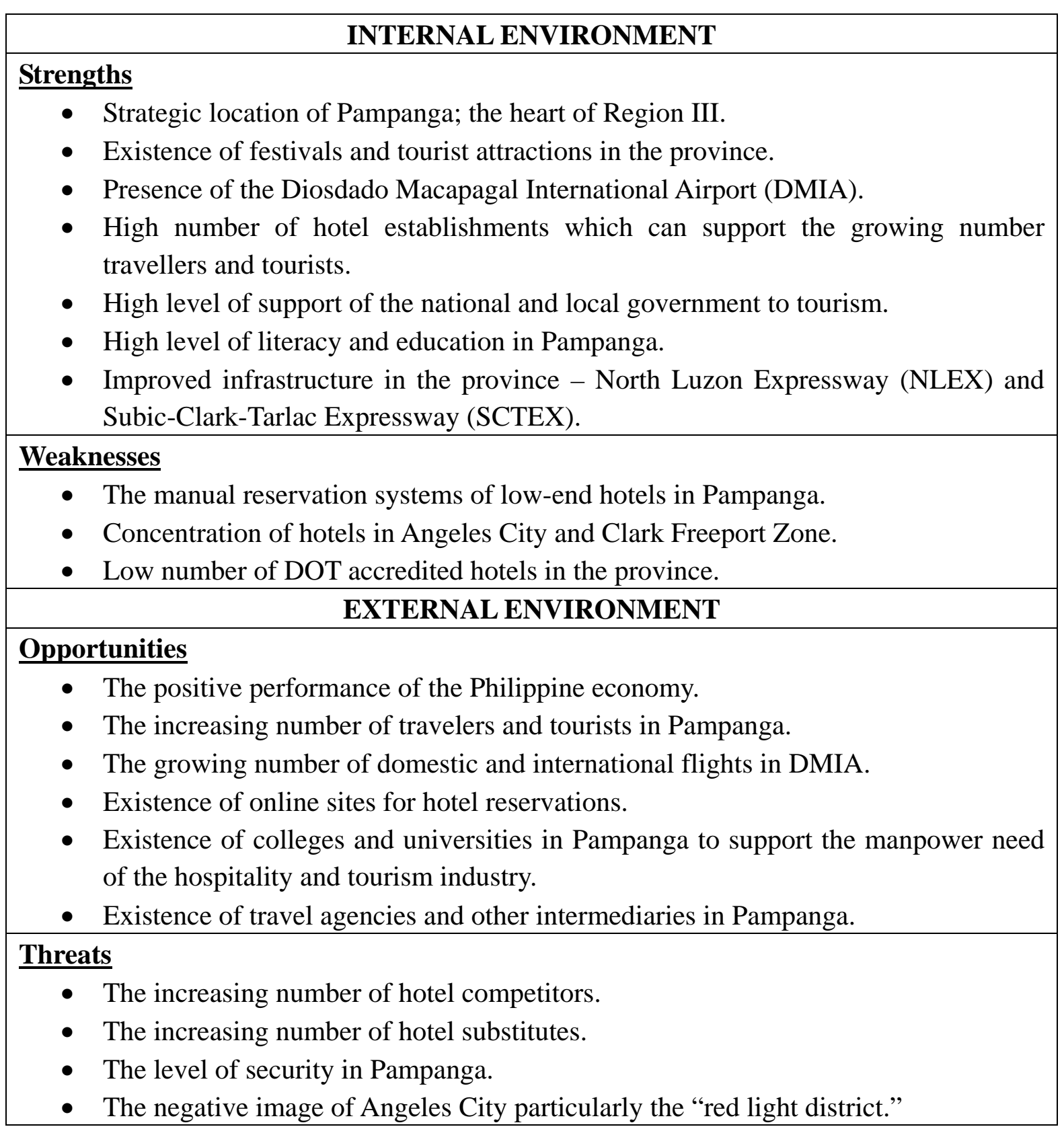

Same as other industries, the hotel industry in Pampanga is confronted by several issues, concerns, and prospects. To achieve sustainability and growth, the industry has prospects that will benefit every hotel establishment in the province.

From the output of the structured and semi-structured interview done by the researcher, the following are the issues, concerns, and prospects of the hotel industry in Pampanga:

1) The low level of support of the local/regional DOT to the hotels in Pampanga in attracting local and/or domestic tourists and travelers.

2) The high level of competition existing in the hotel industry in Pampanga. 


\section{Macrothink}

3) The impact of influx of international tourists and travelers once DMIA will fully developed into a full-blown world-class international airport.

4) The changing pattern of travelers and tourist demographics and its impact on the hotel industry. More and more travelers and tourists are younger generations including yuppies.

5) The negative image of Pampanga especially Angeles city as a "red light district.”

6) Problems arising from technology.

7) Availability of quality human capital.

8) Prospects of the hotel industry in Pampanga.

\subsection{Augmenting the Competitiveness of the Hotel Industry in Pampanga}

From the output of the Porter's Five Forces Model and SWOT analysis, there should be strategic framework to overcome the weaknesses and minimize the threats of the external factors while promoting and augmenting the strengths and taking advantage of the opportunities in the external environment. In coming up for a strategic framework, the researcher collated the results of the structured and semi-structure interview and unified them with the output of the competitive position analysis (through Porter's Five Forces Model) and identified sustainable niche of the hotel industry in Pampanga (through SWOT analysis). From a thorough and extensive scrutiny, the researcher formulated a framework to augment the level of competitiveness of the hotel industry in Pampanga as shown in figure 2.

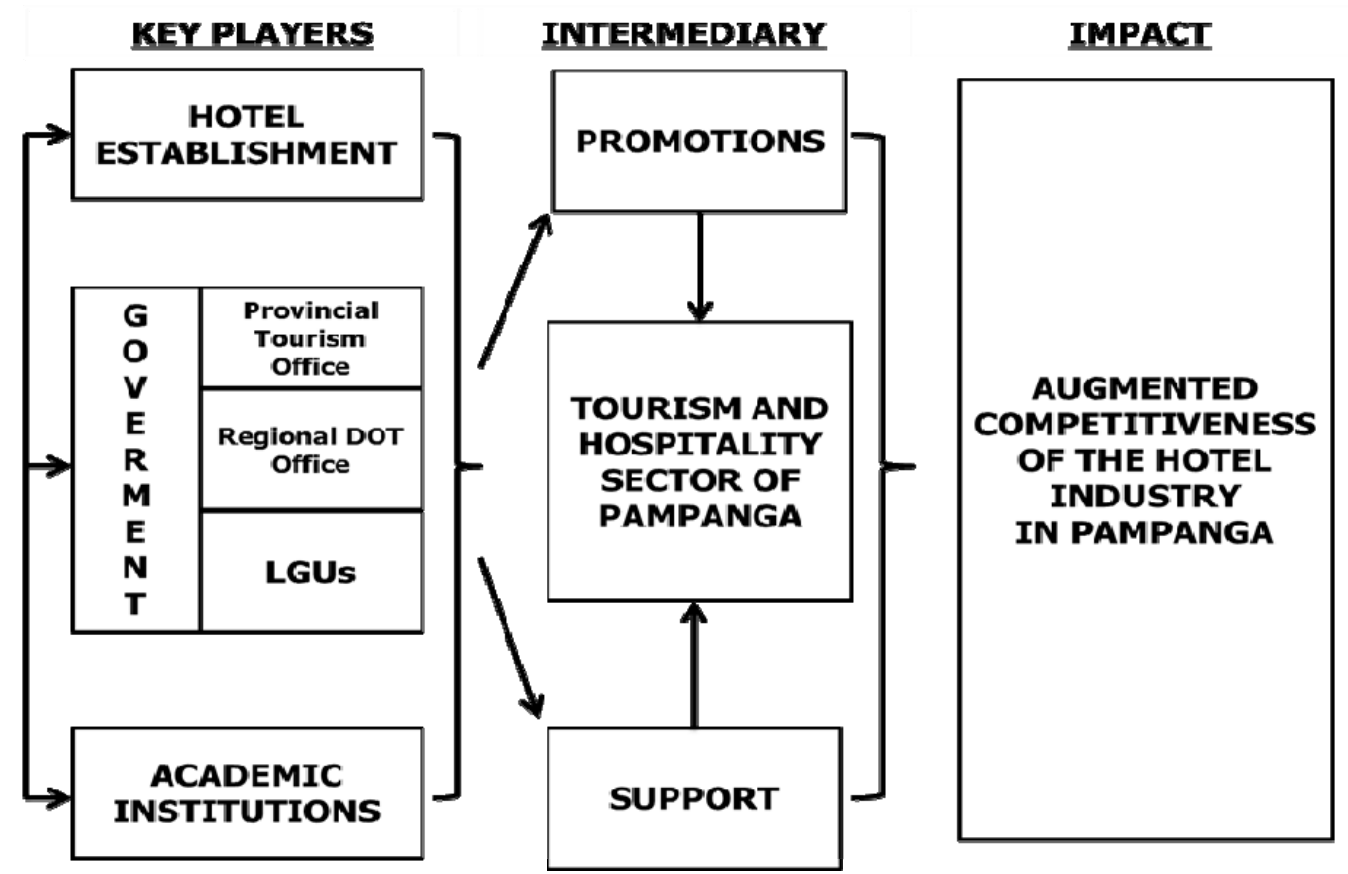

Figure 2. Framework in augmenting the competitiveness of the hotel industry in Pampanga 
Each hotel establishment plays an integral role in the promotion of the tourism and hospitality sector of Pampanga. The role of hotels is providing quality accommodation facilities that meet or even exceed hotel clients' expectations. The growing number of international travellers in DMIA entails a huge challenge to the hotel industry. Every time hotel client feels satisfaction from the products and services provided by hotel establishments, the possibility of repeat purchase is high. Thus, the creation of lasting relationships with hotel clients can lead to customer loyalty and retention.

On one hand, the provincial tourism office should be responsible for the total promotion of the tourism and hospitality sector of the province. At the same time, it should be responsible in supporting and strengthening the different tourism and hospitality events, projects, and activities of the different cities and municipalities of Pampanga. Integration of these tourism and hospitality events, projects, and activities can increase and boost the overall tourism and hospitality sector of the province. Furthermore, the regional DOT office should make necessary sustainable plans for all the private and public organizations that provide tourism and hospitality products and services to tourists and travellers. Through this process, the socio-economic benefits will create multiplier and ripple effects in the industry. The DOT regional office should also be responsible in putting down the DOT's plans and prospects into provincial/local level. As a government unit, one of its biggest challenges is the integration of the provincial tourism office and the local government units' (LGUs) tourism offices. Moreover, the local government units (LGUs) of the Pampanga through their city tourism office or municipal tourism office must develop tourism plans aligned to the provincial tourism plan of Pampanga. The tourism plan should lean toward the promotion of the local tourism and hospitality. Through this, each local tourism plan becomes an integral part of the whole tourism and hospitality sector of Pampanga.

The academic sector represented by academic institutions in Pampanga is responsible for the reinforcement of tourism and hospitality programs. Since the academic sector is responsible for supplying the human capital requirements of the hotel industry in the province, the assurance of producing quality graduates is an imperative. The overall growth of the tourism and hospitality sector would also reflect growth in the overall human capital requirement of the industry.

\subsection{Achieving Hotel Industry Sustainability}

Conversely, the three key players should formulate different strategies aimed at achieving sustainability in the hotel industry in Pampanga. The first strategy is to come up a clear brand image that will capture what the province can offer to tourists and travellers. This will result to a much clearer and sustainable campaign message to the people and will generate awareness with the strengths of the province including culinary, cultural heritage, and colorful festivals. Second is to plan sustainable tourist activities. Despite the fact that Pampanga offers so many festivals and tourist activities, the province does not generate much revenue from it. For instance, the province is known for Giant Lantern Festival, the key players should come up with sustainable activities such as lantern making for tourists 
experience in order to create sustainable economic activity. Third is to push for the new system of hotel accreditation. Presently, DOT uses the metrics de luxe (highest classification), first class, standard, and economy (lowest). The international hotel classification follows the star system ( 1 star - lowest classification; 5 star - highest). This will make the hotels more competitive. It is also an imperative to require hotels to be DOT and LGU accredited. The DOT and the LGU should also work hand in hand in accrediting hotels. Hotels should be required to be DOT accredited before giving them permits to operate to assure quality service to hotel clientele. The basic premise must be a hotel should not only be LGU accredited but also DOT accredited. Fourth is to implement properly all traffic regulations in the province for the convenience of travellers and tourists. Accessibility and convenience should be the primary consideration with this strategic move. The provincial government together with the LGUs should promote security in the province to attract more travellers and tourists since it is a major factor they consider when travelling. This will either make or break the image of Pampanga as a tourist destination. Fifth is to concentrate LGU and local DOT resources in promoting Pampanga as a province of cultural heritage and home of colorful festivals. Pampanga is rich in century-old churches and magnificent festivals such as Sinukwan Festival, Tugak Festival, and Giant Lantern Festival. All promotional efforts and campaigns should be channeled on this goal. Sixth is to assure first that the infrastructures in Pampanga are ready enough before developing DMIA into a world-class airport. The DOT together with the related agencies should create a concrete plan in improving the infrastructures of the province to cope with the possible upsurge with domestic and international passengers in DMIA. Lastly, invest in technology-enabled hotel reservation system. Hotel establishments should invest in technology-enabled hotel reservation system to increase efficiency and productivity in hotel operations and services. This strategic move is vital in augmenting the level of satisfactions from the hotel clientele. Providing trainings related to computerized systems are also necessary. Hotel establishments together with DOT regional office should provide trainings on technology-enable reservation system. This retooling strategy will enhance the skills of hotels and hotel manpower with the use of technology thus increasing their level of productivity. 


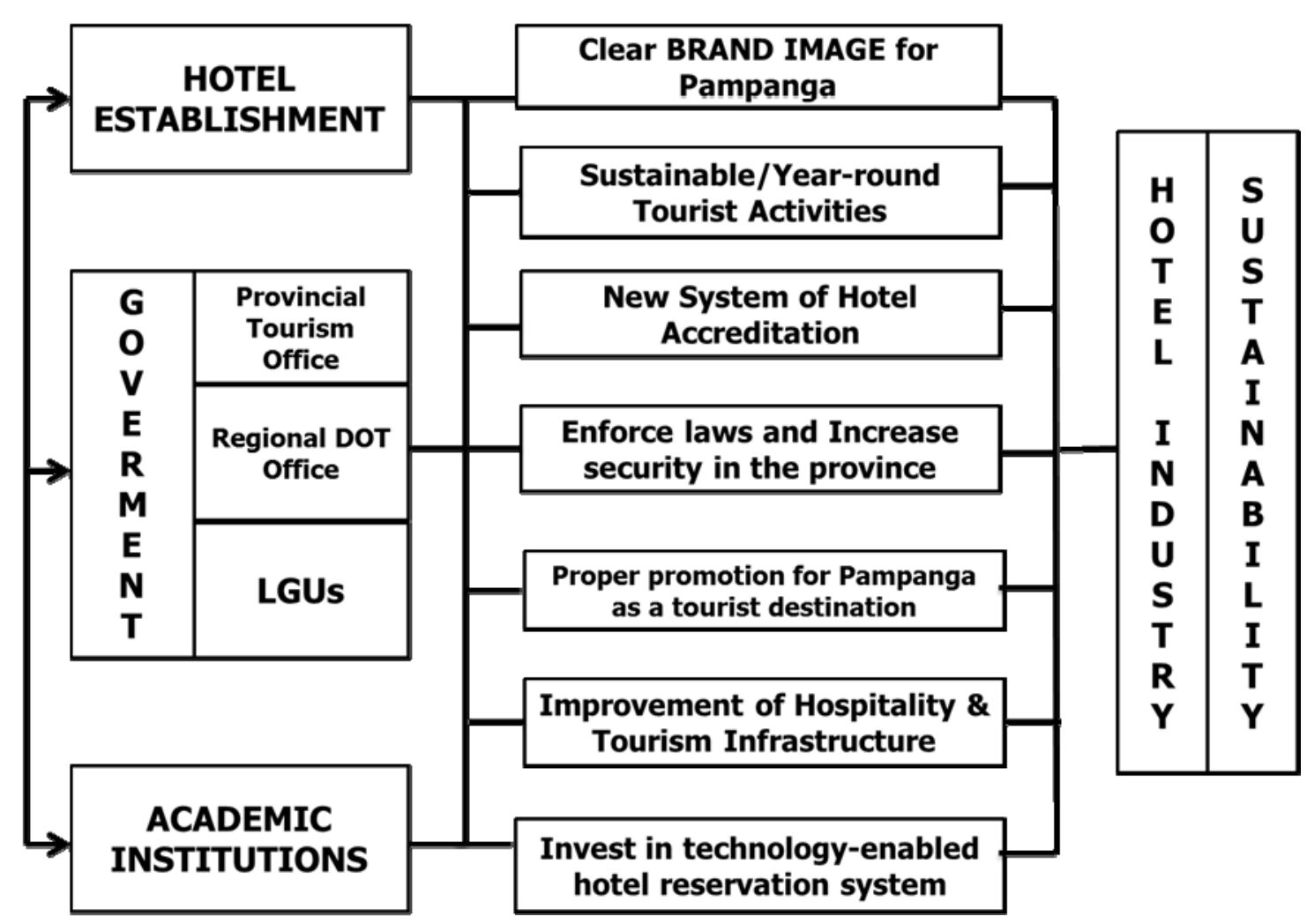

Figure 3. Framework to achieve hotel industry sustainability

Thus, the framework in figure 3 can definitely sustain growth in the hotel industry in Pampanga and certainly contribute to economic prosperity of the province.

\section{Conclusions and Recommendations}

The research study concludes that the hotel industry in Pampanga is competitive as seen in the competitive position analysis. Additionally, there are different factors affecting the internal and external environments of the hotel industry in Pampanga as evidenced in the SWOT analysis done. Despite the bright future of the hotel industry in Pampanga brought about by internal and external factors, still, hotel owners and managers expressed their issues and concerns that can directly and indirectly affect the hotel industry in general. Strengthening the tourism and hospitality sector of Pampanga is a prerequisite to augment the level of competitiveness of the hotel industry. On one hand, sustainability can only be achieved if there will be concrete strategic plans aimed at creating economic activities in the hospitality and tourism sector thus positively affecting the hotel industry in Pampanga.

It is recommended that the two frameworks - competitiveness and sustainability - be the springboards in formulating strategic, business, and tactical plans for the hotel industry in Pampanga. The success of hotel industry can contribute a lot not only in Pampanga but also in the region. 


\section{References}

Bayraktaroglu, S., \& Kutanis, R.O. (2003). Transforming Hotels into Learning Organizations: A New Strategy for Going Global. Tourism Management, 24(2), 149-154. http://dx.doi.org/10.1016/S0261-5177(02)00061-4

Department of Tourism. (2012). Distribution of Regional Travelers by Region, 2010/2009. Retrieved November 10, 2012, from http://e-services.tourism.gov.ph:8080/didcs/Static\%20Documents/summarybyregion\%202010 \%20revised.pdf

Enz, C. A. (2010). Hospitality Strategic Management: Concepts and Cases. New Jersey NJ: John Wiley \& Sons, Inc.

Holjevac, I.A. (2011). Work Productivity in the Croatian Hotel Industry - Fundamentals and Concepts for Achieving Growth and Competitiveness. South East European Journal of Economics and Business, 5(1), 85-90. http://dx.doi.org/10.2478/v10033-010-0008-1

Ioncica, M., Tala, M., Brindusoiu, C., \& Ioncica, D. (2008). The Factors of Competitiveness in the Hospitality Industry and the Competitive Strategy of Firms. Annals of the University of Oradea, Economic Science Series, 17(2), 213-218.

Navarro, J. G. C., \& Martinez-Martinez, A. (2007). Improving Competitiveness Through City Marketing in Spanish Hotels. The Service Industries Journal, 31(9), 1489-1503. http://dx.doi.org/10.1080/02642060903580615

Nurittamont, W. (2012). The Relationship Among Organizational Commitment, Self-Efficacy, and Businesses Performance: An Empirical Study of Hotel Businesses in Thailand. Journal of Academy of Business and Economics, 12(1), 99-109.

Nyheim, P., McFadden, F., \& Connolly, D. (2004). Technology Strategies for the Hospitality Industry. New Jersey NJ: Pearson Prentice-Hall.

Ooncharoen, N., \& Ussahawanitchakit, P. (2008). Building Organizational Excellence and Business Performance of Hotel Business in Thailand: Effects of Service Culture and Organizational Characteristic. International Journal of Business Research, 8(1), 13-27.

Petre, A., Stegerean, R., \& Gavrea, C. (2012). Information and Communication Technology Practices and Hotel Competitiveness. Proceedings from the $6^{\text {th }}$ International Management Conference - Approaches in Organisational Management 2012. Retrieved from http://conferinta.management.ase.ro/cd2012/pdf/75.pdf

Rodriguez-Diaz, M., \& Espino-Rodriguez, T. F. (2006). Developing Relational Capabilities in Hotels. International Journal of Contemporary Hospitality Management, 18(1), 25-40. http://dx.doi.org/10.1108/09596110610641957 


\section{Macrothink}

Business Management and Strategy ISSN 2157-6068 2014, Vol. 5, No. 1

Tavitiyaman, P., Qu, H., \& Zhang, H. Q. (2011). The Impact of Industry Force Factors on Resource Competitive Strategies and Hotel Performance. International Journal of Hospitality Management, 30(3), 648-657. http://dx.doi.org/10.1016/j.ijhm.2010.11.010

Tuclea, C. E., \& Padurean, A. M. (2008). Competitiveness in Hospitality Industry: Romanian Style. University of Craiova, Faculty of Economics and Business Administration - Journal Management \& Marketing, 6(1), 105-114.

Woo, K. J. (2007). Strategy and Competitive Advantage of Las Vegas Hotels (Focus on Lessons for the Korean Hospitality Industry). International Journal of Tourism Sciences, 7(1), 79-93.

Wu, S., \& Lu, C. (2011). The Relationship Between CRM, RM, and Business Performance: A Study of the Hotel Industry in Taiwan. International Journal of Hospitality Management, 31(1), 276-285. http://dx.doi.org/10.1016/j.ijhm.2011.06.012 